\title{
Analysis Principles Of Criminal Law In Article 72 Qanun Of Aceh No. 6 Of 2014 On The Jinayat Law
}

\author{
Dhanar Dhono Vernandhie $^{1}$ and Sri Kusriyah ${ }^{2}$
}

\begin{abstract}
This study describes the applicability of Qanun of Aceh No. 6 of 2014 on the Jinayat law (Qanun of Jinayat) in the order of legislation in Indonesia. Therefore this study to analyze these issues, to examine the legality principle as stated in Article 72 of the Qanun of Jinayat and the rule of law by applying the Qanun of Jinayat. This study uses normative research approach, by analyzing the legal ingredients of primary legal materials, secondary and tertiary. The results and discussion of the research was that Qanun of Jinayat not contrary to the order of Indonesian legislation, both formal legislative process and substantive elements of the rule of law which includes setting legal subjects, actions and sanctions of criminalization. Applicability of Qanun of Jinayat also related to three factors, namely philosophical which is a reflection of the values of the people of Aceh, sociological factors are the result of legal politics of the Government of the Republic of Indonesia and the Free Aceh Movement and the factors juridical is the order of the constitution and legislation that higher. Qanun of Jinayat law enforcement requires the law enforcement agencies, particularly the police for continued and consistent enforcement in order to create legal certainty. Suggestions can be submitted is law enforcement-led policy-making and increased synergies between law enforcement agencies in law enforcement for action based on Qanun of Jinayat Jarimah regulated in Qanun of Jinayat.
\end{abstract}

Keywords: Qanun of Jinayat in Aceh; Legality; Legislation; Law Enforcement.

\section{Introduction}

As the law states, the Republic of Indonesia has a destination country, it is stated in the preamble of the Constitution of the Republic of Indonesia in 1945, which reads: "Protecting the entire Indonesian nation and the entire homeland of Indonesia, promote the general welfare, educating the nation, implementing world order based on freedom, lasting peace and social justice."

To achieve this goal the country is not an easy thing, but it required the development of laws based on the practice of Pancasila values so that the law is a reflection of the values of the nation and state of Indonesia. The advent of the era of reform, development of the law through national legislation in Indonesia undergo changes that affect the social and political life. As according to Aziz (Journal, 2016) states: "The demands were then echoed by elements of society to improve the condition and structure of the post-New Order of Nation. These demands are as follows; (1) amandement 1945; (2) Elimination of the dual function of the armed forces; (3) The enforcement of the rule of law, promotion of human rights (Human Rights), and the eradication of corruption, collusion and nepotism; (4) decentralization and equitable

\footnotetext{
${ }^{1}$ Student of Master of Law, Universitas Islam Sultan Agung Semarang and Police Member, email: dhanartenor90@gmail.com, 082184477774

${ }^{2}$ Lecturer of Master of Law, Faculty of Law, UNISSULA, Semarang
} 
relationship between central and local (regional autonomy); (5) embodies the freedom of the press; and (6) creating a democratic life. "

In particular, regarding the aspects of decentralization and equitable relationship between the central and regional governments, underwent a reform in the system of local government administration. Focused on Act No. 18 of 2001 on Special Autonomy for Aceh Special Province as Nanggroe Aceh Darussalam, Aceh is the only province in the framework of the Unitary Republic of Indonesia, which has special authority to implement Islamic law. It is implemented by the establishment in which Qanun also regulates the criminal law of Islam (Jinayat).

There are pros and cons of the Qanun of Jinayat especially regarding Qanun of Jinayat position in the hierarchy of legislation. Problems arise due to the determination of the principles in the Qanun of Jinayat partly in contrast to the principles of criminal law in Indonesia. As the findings of the authors in Article 72 of the Qanun of Aceh No. 6 of 2014 on the Jinayat law states that "in case there is a deed Jarimah as stipulated in Qanun and arranged also in the Code of Penal (Penal Code) or criminal provisions outside the Criminal Code, which applies Jarimah is the rule in this Qanun ". Thus, it can be perceived that the Qanun of Jinayat can mengeyampingkan the Criminal Code if a deed stipulated in Qanun of Jinayat also regulated in the Criminal Code. ${ }^{3}$

The dynamics of law enforcement Jinayat by Qanun No. 6 of 2014 on the Jinayat law in Aceh can be inventoried in two respects, namely the concerns lack of legal certainty in the application, because of the element of conflict between the substance Qanun with Codes itself. While on the one hand, the Aceh government believes that the presence of the Qanun of Jinayat can provide protection to the weaker levels of society. Applicability of Qanun of Jinayat also have an impact on the political dynamics of Indonesian law, which helped bring the impact on the dynamics of the juridical. ${ }^{4}$

On the one hand inexplicable dualism Criminal Law stipulated in Indonesia's Criminal Law as something of a general nature as set out in the Criminal Code (the Code of Penal Code) which is regulated by Act No. 1 of 1946 on the draft Criminal Code, including applicable for Aceh because Aceh is an integral part of the unitary Republic of Indonesia. But the birth of the Qanun were based on the Islamic Sharia and made by the people of Aceh itself as something provision that much more special because Aceh has been given autonomy as possible to implement Islamic Sharia-based Act No. 18 of 2001 on Special Autonomy for Aceh Special Province as Nanggroe Aceh Darussalam. ${ }^{5}$

Criminal law as one part of the law in general do not show a difference with the law in general, which contains provisions to ensure that the norms recognized in the law will actually be adhered to person. While the purpose of the general law creates a situation in the social life in the community, both in small environments or in larger environments so that in it there is a harmony, order, rule of law and others. ${ }^{6}$

\footnotetext{
${ }^{3}$ Topo Santoso, 2016, Asas-Asas Hukum Pidana Islam, PT. Rajagrafindo Persada, Jakarta, p. 228.

${ }^{4}$ Abdul Manan, 2006, Aspek-Aspek Pengubah Hukum, Kencana Prenada Media, Jakarta, p. 6

${ }^{5}$ Topo Santoso, 2016, Asas-Asas Hukum Pidana Islam, PT. Rajagrafindo Persada, Jakarta, p. 231.

${ }^{6}$ Barda Nawawi Arief, 2008, Bunga Rampai Kebijakan Hukum Pidana (Perkembangan Penyusunan Konsep KUHP Baru), Prenadamedia Group, Jakarta, p. 28.
} 
In addition, efforts to address crime through criminal law making essentially also an integral part of the business community protection. Therefore, it is natural that political policy or criminal law is also an integral part of the policy or social policy. Social policy can be defined as any rational effort to achieve the welfare of society and also includes protection of the public. ${ }^{7}$ Based on these things then, writers felt the need to examine the cargo formulate the problem as follows: How the application of Article 72 of the Qanun of Aceh No. 6 of 2014 on the Jinayat law associated with the principles of the criminal law set out in the Criminal Code? How can law enforcement actions against regulated in Qanun of Aceh No. 6 of 2014 on the Jinayat law?

\section{Research methods}

The author uses such research approach, the approach of legislation, case-based approach, analytical approach and historical approach. The type of research in writing used by the author is the type of descriptive analytical study doctrinal law. The data sources used are of legal materials which consist of primary legal materials, secondary law and tertiary legal materials. The collection of primary legal materials, secondary law and tertiary legal materials is carried out through the mechanism of inventory, identification by using indices of law (legislation index, an index of a court decision). In the collection of legal materials on the author also provides a response to legal materials used. Subsequent legal materials analyzed qualitatively, with categorization as a preliminary step to classify material selectively law. Later, studied in descriptiveanalytic manner described, analyzed, systematized, interpreted, and evaluated the positive law. ${ }^{8}$

\section{Results and Discussion}

\subsection{Application of Article 72 of the Qanun of Aceh No. 6 of 2014 on the Jinayat law Associated With Principles In Criminal Law Regulated In the Criminal Code}

Article 72 of the Qanun of Aceh No. 6 of 2014 on the Jinayat law mention:"In case there Jarimah acts as stipulated in Qanun and arranged also in the Code of Penal (Penal Code) or outside the criminal provisions in the Criminal Code, which applies is the rule Jarimah in this Qanun".

Viewed from the perspective of systematic legal interpretation explained that the enactment of Article 72 of the Qanun of Jinayat through is not something contrary to positive law issues. Legislation Qanun of Jinayat when viewed in terms of its formation has complied with the formal establishment of legislation, are as follows:

- In view of Article 18 (6) UUD 1945;

"The regional government has the right set of local regulations and other regulations to implement autonomy and duty of assistance"

\footnotetext{
${ }^{7}$ Nandang Sambas \& Ade Mahmud, 2019, Perkembangan Hukum Pidana dan Asas-Asas dalam RKUH, PT. Refika Aditama, Bandung, p. 12.

${ }^{8}$ Jonaedi Efendi, 2016, Metode Penelitian Hukum Normatif dan Empiris, Kencana, Jakarta, p. 183
} 
- Article 18 B 1945;

- The State recognizes and respects the local government units are special or that are regulated by law.

- The State recognizes and respects units of indigenous and tribal peoples and their traditional rights long as they live, and in accordance with the development of society and the principles of the Unitary Republic of Indonesia, which is set in the legislation.

- Article 29 UUD 1945;

- Based State Almighty God.

- State guarantees the freedom of each citizen to profess his own religion and to worship according to his religion and beliefs it.

- Aceh as part of the Unitary Republic of Indonesia has the Privileges and Special Autonomy, one of them the authority to implement the Islamic Sharia, to uphold justice, welfare and legal certainty; and

- Based on the mandate of Article 125 of Act No.11 Of 2006 concerning Aceh Government, Jinayat law (Criminal Law) is part of the Shari'a implemented in Aceh; In the conduct of governmental affairs regional authority, confirmed that regional governments run the widest possible autonomy to organize and manage their own affairs is based on the principle of autonomy and duty of assistance, except for governmental affairs determined the affairs of the central government. ${ }^{9}$ To that end, it is necessary to harmonize the legal principle of these materials in a positive legal regulations. The general principles of law, namely the legal principle of lex specialis and Lex superior legal principle Derogat Legi Inferiori.

Article 72 of the Qanun of Aceh No. 6 of 2014 on the Jinayat law is manifestation of the principle of lex specialis which Qanun is a special rule that applies only in Aceh and disregard the general rule that existing national criminal law in the Criminal Code. Then, the principle of Lex superior Derogat Legi Inferiori, very clearly Qanun of Jinayat a mandate and a reflection of the rules of the Act thereon. Qanun which equated to gain legitimacy through local regulation 3 (three) legislation, namely:

- Act No.44 Of 1999 on the Implementation of Special Province of Aceh;

- Act No.11 Of 2006 concerning Aceh Government; and

- Act No.48 Of 2007 concerning the Stipulation of Government Regulation in Lieu of Act No. 2 of 2007 on the Handling of Legal Issues in the Framework of Rehabilitation and Reconstruction of Public Life in Aceh and Nias, North Sumatra.

In connection association principles in national criminal law, including the principle of legality by Qanun of Jinayat Aceh, explained that in the positive law and its development in Indonesia, the principle of legality is not solely defined as Nullum Delictum Sine Lege, but also as Nullum Delictum Sine lus ie to recognize the criminal law in this case Qanun of Jinayat of Aceh which are laws that live in the community as a source of law. The passing of Qanun of Jinayat as written criminal law rules applicable in the territory of Aceh has fulfilled the legal certainty the principle of legality.

\footnotetext{
${ }^{9}$ Article 10 paragraph (2) and (3), Act No. 32 of 2004
} 
Qanun of Jinayat of Aceh also has two functions when viewed from the principle of legality, which is a function instrumentation and protection functions. Instrumentation functions related to the implementation of the state in order to enforce the Qanun of Jinayat towards legal subjects that do or do not do anything that is regulated in Qanun of Jinayat punishable by Jinayat, as well as to the subject matter of the law can be accounted for mistakes. Then, relating to the protection function is that the citizens understand in writing of any behavior-behavior that is prohibited behavior and if violated would be punishable by Jinayat. In addition to its association with the principle of legality principles in national criminal law with Qanun of Jinayat of Aceh, also includes the territorial principle, the principle of personal and universal principles. Qanun of Jinayat enforceability only on the plains of Aceh and does not apply to a vessel or vehicle.

Then, in terms of the principle of national personal, Qanun of Jinayat of Aceh not describe personal principle in setting legal subjects. Furthermore, in terms of national universal principles, applicability Qanun of Jinayat of Aceh as contained in Article 5 Qanun of Jinayat. Pursuant to Article 5 of the Qanun of Jinayat that contained an absolute Qanun of Jinayat applies to followers of Islam who acts Jarimah, notwithstanding the fact that followers of Islam are not domiciled in Aceh. Then, Qanun of Jinayat apply in the presence of certain conditions for religion is not Islam, that is subjectively or objectively. Subjectively meaningful measure of a psychological condition willingness themselves to lowered themselves to the Jinayat law while objectively meaningful measure of their conditions of participation where people are not Muslims committing Jarimah together with the Muslims and the condition of a legal vacuum if religion is not Islam do deeds included in the deed Jarimah. Lastly, with regard to the expansion of legal subjects that not only assess the human subject as legal or natural person, but also regulate the legal subject in the form of business entity or recht persoon.

Political factors also contributed in the formation of Qanun as the applicable law in Aceh. Qanun of Jinayat is a form of implementation of the Memorandum of Understanding between the Government of the Republic of Indonesia and the Free Aceh Movement (Memorandum of Understanding between the Government of Republic of Indonesia and the Free Aceh Movement, Helsinki 15 August 2005), the Government of the Republic of Indonesia and the Free Aceh Movement reiterated their commitment to finish Aceh conflict peaceful, comprehensive, sustainable and dignity for all, and the parties are determined to create the conditions so that the People's Government of Aceh can be manifested through a fair and democratic process within the unitary state of the Republic of Indonesia.

\subsection{Law Enforcement Against Arranged Deeds In Qanun of Aceh No. 6 of 2014 on the Jinayat Law}

As a process, law enforcement is essentially a variable that correlated and interpendent with other factors. There are several related factors determine the law enforcement process. According to Lawrence M. Friedman explained that there are three (3) components in the success of law enforcement is a component of substance, structural components and components of the legal culture. 
In substance, according to the author that the difference between the Qanun of Jinayat with national criminal law should not be considered a legal battle that can be destructive to the legal system. But otherwise these differences can be used as a legal reform that reflects that there is a diversity in the legal community in Indonesia. Meanwhile, in terms of the substance of that material in the Qanun of Jinayat not contrary at all criminal laws governed by Islamic law. Only Qanun not adopt all the rules of Islamic criminal law. It is examined from the criminal law in the form of sanctions, orders and / or prohibitions, where sanctions, orders and / or prohibition must be obeyed by all people, each person shall act in such a way in the community, The next component is the legal structure. Institutions related to the execution of Islamic law in the province is as follows: Department of Islamic Sharia, the WH, police, prosecutors, the Shariah Court and the Council of Indigenous Aceh.

One law enforcement jobs the most interesting is the work of the police and also the restrictions regarding the discussion of structural components. Police are seen as living law, because the law in the hands of the police suffered embodiment, at least in the area of criminal law.

Being a part of law enforcement agencies, local police in Aceh have specificity in the execution of his duties. Where in addition to serving as a law enforcement police also serve as enforcers of Islamic law in Aceh. In carrying out the obligations of law enforcement, police grounded in Article 2 of Act No. 2 of 2002 on the Indonesian National Police, namely: "The function of the police is one of the functions of state government in maintaining security and public order, law enforcement, protection, shelter, and service to the community".

Whereas in Islamic law enforcement duties, Police of Aceh is based on Article 133 of Act No.11 Of 2006 concerning Aceh Government, namely: "The task of the investigation to the enforcement of sharia law under the authority of the Court Syar'iyah along the jinayah conducted by the Indonesian National Police and Civil Servant Investigators".

Police in Aceh as part of law enforcement agencies are required to implement any rule contained in the Qanun Jarimah where Qanun is part of the substance of the law enforcement component. Thus the necessary legal culture contained in the legal structure, in this case the Aceh Police to implement Qanun of Jinayat of Aceh occurs when the offenses stipulated in Qanun of Jinayat.

Next is associated with a third component that is culture as a determinant of the success of law enforcement. Cultural factors in law enforcement basically covers the underlying values of the applicable law, the values of which are abstract conceptions of what is good (so followed) and what is considered bad (thus avoided). In the criminal law field-value pairs used is order and peace are aligned with the public interest. Perceptions of what is good and what's so follow avoided in terms of the perception of which is owned by the people of Aceh Acehnese that formal legislation requires the enforcement of Islamic law.

The enforceability of a legal norm with the fact whether it is appropriate or not to be measured of legal awareness and legal culture of society, so that the legal norms accepted by the society. Furthermore, to show fairness and certainty, then the norms of the law should be applied by law enforcement agencies in the Qanun of Jinayat is 
Aceh Police. In addition to the discussion of law enforcement in the systemic approach, the rule of law as a social process is also influenced by a factor of five law enforcement, as proposed by Soerjono Soekanto, that factor alone law, law enforcement apparatus, means factors, community factors and cultural factors.

In the first factor, namely the legal factors alone. When connected with Qanun of Jinayat rule it meets the principles of the formation of the rule, as did similar when linked with the establishment of guidelines for the rules. Qanun of Jinayat formed on the basis of the noble desire of Acehnese society in the framework of the legislation of Islamic law into positive law of the state. Qanun their Jinayat can be used as progresive law in Indonesia that would create a legal harmony path. Qanun of Jinayat is part of the values of diversity at the level of the Homeland. Lack of diversity gives the container at the beginning of many events upheaval and even to the uprising in Indonesia.

On the second factor, namely the factor of law enforcement. This factor is of particular interest, because of the impact and evaluation of the effectiveness of Qanun of Jinayat rules that are in power and authority of law enforcement. The rules prohibited or ordered if it is not enforced by law enforcement, would be writings in legal texts. In law enforcement factor focuses on the role of law enforcement, law enforcement agencies are required to run a role that should have been regulated in Qanun of Jinayat rules. Law enforcement officials are required to overcome the obstacles that occur both in subjective oneself or of an objective based on the actual conditions.

On the third factor, that factor means. Factors include the facility needs a capable human resources, budget requirements, material requirements, corporate governance requirements and needs with fittings justice. The need of these facilities are the conditions for the attainment of the objectives of the factors is the means of achieving certainty and speed in the judicial process, so that the legal subjects that deal with the law receive the guarantee of their rights.

On the fourth factor, the factor of society, that in Aceh there is a class of people who want Qanun of Jinayat use rules other than by reason of sanctions in the Qanun of Jinayat lighter than the rule in some cases beyond Jarimah Qanun. It is like the opinion Soekanto Soerjono can cause confusion thinking to decide whether the Qanun or other rules are used. Surely this can be overcome if the law enforcement agencies with full awareness and understanding of good and consistent to apply the rules in Qanun of Jinayat.

In the fifth factor, the cultural factors. Culture in the legal system is the underlying values of the positive law, these values are an abstract concept associated with what is considered to be performed or otherwise what is considered to be not done. Qanun of Jinayat is in conformity with the values desired by the people of Aceh. Thus, as the container form Qanun reflection of the implementation of the Law on the Governing of Aceh so that the implementation of Islamic Sharia in all lines of life of the people of Aceh, is also a form of implementation of the balance value with the value of material as well as the implementation of innovative value from the perspectives of national law reform.

\section{Closing}




\subsection{Conclusion}

Based on the above discussion the authors conclude as follows:

- Application of Qanun of Aceh No. 6 of 2014 on the Jinayat law not conflict with laws and regulations, both in the formal hierarchy of legislation and in terms of the material substance of the arrangements regarding the subject of legal action and sanction criminal prosecution. This is because the process legislation of Qanun of Jinayat of Aceh has been in accordance with the legal foundation of the formation of the philosophical, sociological and juridical.

- Enforcement of the law, in this case carried out by the police with a foundation substance Qanun of Aceh No. 6 of 2014 on the Jinayat law not done continuously and consistently, it is because there is a demand of the litigant parties not to use Qanun of Jinayat of Aceh.

\subsection{Suggestion}

As for practical advice to the authors propose is to educate law enforcement officers to carry out capacity building through short courses related to the implementation of the law enforcement Qanun of Jinayat and increased synergy between the law enforcement agencies. Then, the required policy decisions by the leadership of law enforcement agencies regarding the implementation of law enforcement to act Jarimah using Qanun of Jinayat of Aceh in order to create legal certainty and eliminate the perception of duality law in Aceh.

\section{References}

[1] Topo Santoso, 2016, Asas-Asas Hukum Pidana Islam, PT. Rajagrafindo Persada, Jakarta.

[2] Abdul Manan, 2006, Aspek-Aspek Pengubah Hukum, Kencana Prenada Media, Jakarta.

[3] Topo Santoso, 2016, Asas-Asas Hukum Pidana Islam, PT. Rajagrafindo Persada, Jakarta.

[4] Barda Nawawi Arief, 2008, Bunga Rampai Kebijakan Hukum Pidana (Perkembangan Penyusunan Konsep KUHP Baru), Prenadamedia Group, Jakarta.

[5] Nandang Sambas \& Ade Mahmud, 2019, Perkembangan Hukum Pidana dan AsasAsas dalam RKUH, PT. Refika Aditama, Bandung.

[6] Jonaedi Efendi, 2016, Metode Penelitian Hukum Normatif dan Empiris, Kencana, Jakarta

[7] Act No. 32 of 2004 